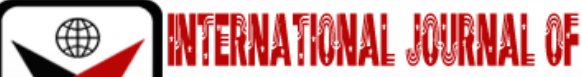

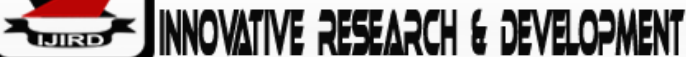

ISSN 2278-0211 (Online)

\section{Impact of Jolly Phonics Teaching Method on the Formation of Letter Sounds Abilities of Primary School Pupils in Gusau Local Government of Zamfara State, Nigeria}

\author{
Hussain Aliyu \\ Lecturer, Department of English, Federal College of Education (Technical), \\ Gusau, Zamfara State, Nigeria
}

\begin{abstract}
:
The study focused on the impact of Jolly Phonics method on the formation of letter sounds abilities of primary school pupils in Gusau local government of Zamfara State, Nigeria. Two research questions were developed and answered in line with what the study sought to find out. Also two null hypotheses were formulated and tested at the probability of 0.05 levels of significance. The study made use of Burt and EGRA reading and writing tests to ascertain pupils' baseline in word formation and their level of attainment in the same skills after being exposed to Jolly Phonics teaching method. Thereafter, they were subjected to treatment for 6 weeks using adapted Burt-EGRA reading and writing test. The instrument Burt-EGRA reading and writing test was developed from the review of related literature and was used for the treatment of the respondents. The instrument Burt-EGRA reading and writing test validated by experts in Department of curriculum (Language Education) Usmanu Danfodiyo University Sokoto and to ensure reliability of the items, they were pilot tested in two (2) primary schools outside the selected schools within the study area. The entire population for the study was 79,377 pupils and total of 1,901 obtained from the sixteen (16) sampled primary schools selected from the study area. One hundred (100) respondents were sampled out of the total population using stratified simple random sampling technique. The data collected for the study were analyzed using descriptive statistics (mean and Standard deviation) to answer the research questions raised where $t$-test statistical analysis was employed by the researcher to test the null hypotheses. The findings of the study revealed that there was significant difference in the performance of respondents subjected to treatment using Burt-EGRA reading and writing test in teaching Jolly Phonics. It was recommended that enough time should be allotted to the teaching of Jolly Phonics as this will help pupils to improve in their skills of sounds identifications, sound formation and words formation.
\end{abstract}

Keywords: Jolly phonics, reading, writing, identification and formation of letter sounds

\section{Introduction}

This research investigates the effect of Jolly phonics teaching method on reading abilities of primary school pupils inGusau local government, Zamfara State. The term Jolly means 'fun' and phonics refers to letter sounds used for reading. Jolly phonics means reading through play Jolly phonics instructional strategy is a systematic and sequential phonics programme designed to teach children to read and write (Ogbemudia\&Alasa, 2014).

Jolly Phonics is a fun and child centered approach to teaching literacy through synthetic phonics. With actions for each of the 42 letter sounds, this multi-sensory method is very motivating for children and teachers, who can see their students achieve. The sounds are taught in a specific order (not alphabetically). This enables children to begin building words as early as possible. Jolly Phonics teaches children the five key skills for reading and writing. The programme continues through school enabling the teaching of essential grammar, spelling and punctuation skills.

The key advantages of the approach are that it teaches children all the main letter sounds early on and to relate the sounds to the symbols and so understand the alphabetic code used for reading and writing. As a result, the children's achievements are very much greater, not only in reading, but also in their writing. Because the children have a way of writing each letter sound they are able to write whatever they want, early on, in a way that is readable hence, learning to read and write fluently are vital skills for children.

Watson and Johnston (2005) conducted a research in Scotland titled "An Investigation of the Effects of Phonics Teaching on Children's Progress in Reading and Spelling." which shows that the Jolly Phonics method produces skilled readers that also enjoy reading. Children taught using Jolly Phonics were found to be more than 11 months ahead in reading and writing and more than 9 months ahead in comprehension than children taught by other methods. At the end of a seven years study, they concluded that Jolly Phonics has a long lasting effect because the skills of blending and sounding taught to the children early resulted in their ability to handle unfamiliar words even years after they were taught 
using the method. In this present study, the findings revealed a significant improvement in identification of sounds and formation of sound and the pupils could read words and simple sentences after been exposed to Jolly Phonics method.

Eshiet, (2012) conducted a research titled "Synthetic Phonics as a Tool for improving the Reading skills in Nigerian Pupils" The study revealed that; Synthetic Phonics method have demonstrated reading skills far ahead of their contemporaries who were taught using other method. Pupils have shown interest in reading and writing far ahead of others taught using other method. I quite agree with Eshiet findings, after comparing the findings with the present study, the Jolly phonics adopted in Gusau has revealed that the method has helped to improve the reading skills of the pupils and they have demonstrated high level of readiness to read and this has been demonstrated in their performance after been exposed to Jolly Phonics compared to their performance before the approach.

Ekpo et al, (2007), did a 9 month study using Jolly Phonics as an intervention strategy in 5 schools in Akwalbom State, Nigeria. At the end of the study, pupils in the intervention made a gain of 1 month to 31 months in their reading age while those in the control group did not record any improvement. They therefore recommended early Jolly Phonics training, and discouraged the traditional rote learning and drill method. They also recommended that their research should be replicated in other parts of the country. The present study is conducted in Gusau and effort is been made to overcome problem of reading within the study area and at the end the study there was a huge gap in the performance in reading before been exposed to Jolly Phonics.

\subsection{Statement of the Problem}

Attainment of literacy is one of the prime expectations of basic education. Statistical information in this regard is not so encouraging in many developing countries. (EdData), 2010) reveals that the average literacy rate for children in Nigeria 5 to 16 years is $46 \%$. The distribution of this percentage is far from even among the 36 states in Nigeria where some states, especially in the southern part of the country, record up to 75\% while others mostly in the North West and North East of the country record as low as 13\% (EdData, 2010). The report of National Commission for mass Education, (2010) gave a related revelation on the literacy dichotomy in Nigeria with Imo State having the highest literacy rate in English and Lagos having the highest literacy rate in any language. In terms of the six geo-political zones in Nigeria, the report opines: "south East had the highest literacy rate in English while South West had the highest literacy rate in any language, whereas North Central had the least literacy rate in English language with 14.5\%".

One observation that has to be passed on the literacy information on North West and North East Nigeria above is the restriction of the instruments of the research to English and Nigerian Languages and suppressing the factor of literacy in Arabic which millions of people from these zones possess. (National Commission for Mass Education, 2010). A local committee of academics from Nigerian Universities set up to investigate the situation of primary education in Zamfara State (North West Nigeria) also revealed that many children could not read or write after six years of primary education (ZSPEAC, 2012).

A discerning point from the discussion above is that the performance of Nigerian schools has been low in connection to the expectations of making them capable in the literacy requirements of reading and writing. This may not be unconnected with so many factors, among which is the method of teaching English literacy as a national language itself. In a bid to improve on that, Zamfara State adopted Jolly Phonics method of teaching reading and writing, to support the existing traditional method of teaching literacy. To make the project a success, a team of academics from Usmanu Danfodiyo University Sokoto is invited to provide technical support. Thus, the desire to embark on the research is informed by the need to provide information that would facilitate and sustain the continued utilization of the Jolly Phonics method in Zamfara State, Nigeria.

\subsection{Objectives of the Study}

- To find out whether Jolly Phonics Teaching Method has impacted on identification of letter sounds of Primary School Pupils in Gusau local Government, Zamfara State.

- To find out whether Jolly Phonics Teaching Method has impacted on formation of letter sounds abilities of primary school pupils in Gusau local Government, Zamfara State.

\subsection{Research Questions}

- What is the effect of Jolly Phonics on performance of Primary School pupils in identification of letter sounds?

- What is the effect of Jolly Phonics on performance of Primary School pupils in their formation of letter sound abilities?

\subsection{Hypotheses}

The null hypotheses tested are:

- There is no significant difference in the mean scores of Primary School pupils 'performance in identification of letter sounds and the pre-test data in Gusau local Government of Zamfara state.

- There is no significant difference in the mean scores of Primary School pupils' in their formation of letter sounds abilities and the pre-test data in Gusau local Government of Zamfara state.

\section{Review of Related Literature}

From the literature review, it was revealed that the Jolly phonics method produces pupils who can identify letters and form them. Jolly phonics method led to improvement in learning for the pupils. The 'fun' element that is introduced in this method of teaching brought out a new interest in teaching for the pupils as well as the teachers. It is concluded that 
pupils can achieve high identification of sounds, formation of sounds, reading and writing rate if properly taught using Jolly Phonics.

In conclusion, these well-conducted studies constitute a very solid and impressive research base in support of Jolly Phonics around the globe. All the literatures consulted emphasize on reading and reading comprehension or writing skills separately and their findings were all in favour of the use of Jolly Phonics Method to impact on the above mentioned skills. While this research also has a similar findings that revealed that pupils performance have been impacted in identification and formation of letter sounds after been exposed to Jolly phonics method. The uniqueness of this work is that it is being conducted in Zamfara state, and it is the first of its type, it also fills in the gap of identification and formation of letter sounds skills, which is necessary for learners at the formative age.

\section{Methodology}

The research design adopted for this study is an experimental study where data are analysed using pretest and posttest scores of the pupils

The population of this study comprises all the pupils of Primary two (2) in Gusau local government of Zamfara State. There are 79,377 pupils in all the Primary schools in which 100 sample were picked to represent the entire population.

Sampling is a systematic process used to select a required portion of a target population (Dougherty, 2014). This is the procedure which a researcher employs in selecting elements to represent the entire population. The study samples were drawn from the whole population. It is the strategy adopted by the researcher for arriving at a good representation of the population. Stratified sampling is a variation of simple random sampling in which the population is partitioned into relatively homogeneous groups called strata and simple random sample is selected from each stratum. The results from the strata are then aggregated to make inferences about the population.

First, the schools were stratified into Urban and Rural schools and from each of the types one school was selected to represent each i.e. Urban and Rural. The schools from which samples were drawn are shown on the Table 1

\begin{tabular}{|c|c|c|c|}
\hline Name of School & Type & Population & Sample Size. \\
\hline Tudun/Wada MPS Gusau & Urban & 322 & 176 \\
\hline Wanke M.P.S. & Rural & 241 & 144 \\
\hline
\end{tabular}

Table 1: All the Educational Clusters, Sampled Schools and Sample Size

From the above table, a total of 320 Pupils both Males and females out of which 100 were randomly sampled from the selected schools. Therefore, the total sampled 100 respondents for the study are 100 under the expected samples from the whole tables. This agrees with the recommendations of Krejcie\& Morgan (1970) table of determining sample size.

Two standard tests were adopted namely: EGRA (Early Grade Reading Assessment) and BRT (Burt Reading Test) taking cognizance of the pupils level the researcher adapted the following research instruments: The Burt Reading Test (BRT) and Early Grade Reading Assessment (EGRA) items were randomly selected from each instrument taking cognizance of the level of the learners as to come up with one adapted instrument namely: Burt-EGRA reading and writing test that will cater for the need of the target pupils. Items were selected from Burt Reading Test (BRT) and from early Grade Reading Assessment (EGRA). The items selected were merged as one instrument title; Burt-EGRA Reading Test. to test identification and formation of letter sounds abilities of the pupils.

In order to ascertain the extent to which the instruments used clearly measure what they are designed to measure, Burt Reading Test and EGRA (Early Grade Reading Assessment) items were adequately studied, modified and corrected. This was initially done with the help of expert from Department of curriculum (Language education) Usmanu Danfodiyo University Sokoto.

Reliability is the degree of accuracy with which an instrument measures whatever it is measuring. Reliability has to do with consistency and stability of the instrument. To establish the reliability of the instrument of this study test-retest reliability was employed for reporting the correlation co-efficient. Ten Pupils of Sarkin Kudu Model Primary School Gusau and Model Primary School Unguwar Danbaba were selected outside the sampled schools for the identification and formation of letter sounds test.

The identification and formation of letter sounds test was also administered within an interval of two weeks under the same condition. On each occasion of test administration, it took the samples ten minutes (10) for each sample on identification and formation of letter sounds. The score of the sample was recorded in terms of their overall performance on the test and re-test administered. The reliability co - efficient of the test re- test score was computed by means of Pearson Product Moment Correlation Coefficient (PPMCC). This formula was used to ascertain the extent between the first and second tests of the study sample. A reliability co - efficient of $r=0.87$ was obtained, which signify that the instrument is reliable. After the pilot testing all necessary corrections were made items found to be vague or not properly responded to have been modified and some of them changed.

- $\quad$ Each child was tested individually,

- The test was taken in a place that was quiet and free from distractions.

- The child read the words from left to right.

- The test continued until the child made ten (10) errors in succession.

The test was administered to Pupils in Primary 2. The Researcher conducted the test by keeping record of the child's responses as they read through the words in the test. By the use of a photocopy of the test and to tick the correct responses as they are made, the researcher tried not to distract the child when doing so. The sight of a lot of heavily 
written Xs next to words might easily discourage the child, so this was avoided. The researcher kept the record of right and wrong answers out of sight of the child. This method provided comprehensive detail and yielded information relevant to the study that could not have been obtained through the interview and observation methods.

\section{Result}

The data collected were presented in line with the research questions raised for the study as follows:

- Research Question Number 1: What is the effect of Jolly Phonics on performance of Primary School pupils in identification of letter sounds?

\begin{tabular}{|c|c|c|c|}
\hline Test & No of students & Mean (x) & SD \\
\hline Pre-test & 100 & 0.3 & 0.5 \\
\hline Post-test & 100 & 3.66 & 0.65 \\
\hline
\end{tabular}

Table 2: Table Showing the Performance of Pupils' Identification of Letter Sounds

Table 2 revealed the performance of pupils in identification of letter sounds among primary schools pupils in Gusau of Zamfara State of Nigeria. Therefore, the table indicated that the pre-test performance was (0.3) while the posttest was (3.66). The difference observed was further subjected to t-test analysis to find out if it is significant to draw conclusion

- $\quad$ Research question Number 2: What is the effect of Jolly Phonics on performance of Primary School pupils in their formation of letter sounds abilities?

\begin{tabular}{|c|c|c|c|}
\hline Test & No of Students & Mean (x) & SD \\
\hline Pre-test & 100 & 0.5 & 0.3 \\
\hline Posttest & 100 & 2.18 & 938 \\
\hline
\end{tabular}

Table 3: Table Showing Pupils' Performance in

Their Formation of Letter Sounds

Table 3.revealed the performance in formation of letter sounds of primary school pupils in Gusau. The table revealed that the mean scores of pre-test is 0.5 which indicated that the performance was low while the performance in formation of letter sounds among primary school pupils in the post-test is 2.18 indicating that the performance was high. Therefore, the Table indicated a mean gain of 1.68 over the pretest scores. The difference observed was further subjected to t-test analysis to find out if it is significant to draw conclusion

- Ho 1: There is no significant difference in the mean scores of pupils' Posttest performance in identification of letter sounds and the pre-test.

\begin{tabular}{|c|c|c|c|c|c|c|c|}
\hline Variable & No & X & SD & Df & t-cal value & t-crit & Decision \\
\hline Pre-test & 100 & 0.3 & .05 & & & & \\
\hline Post-test performance & 100 & & & 319 & 4.46 & 1.97 & Ho Rejected \\
\hline
\end{tabular}

Table 4: .T-Test Analysis between the Pre-Test and Posttest Scores of Pupils

in identification of Letter Sounds of Primary School Pupils in Zamfara State

As shown in Table 4. The $t$-cal value (4.46) was $>$ than the t-crit (1.97) for 320 degree of freedom at 0.05 alpha level of significance. This indicates that the null hypotheses which stated that there is no significant difference in the mean scores of pupils' performance in identification of letter sounds and the pre-test is rejected. Therefore, the alternative hypothesis is upheld that means that there is positive significant difference between the pre-test performance of the pupils and those that are taught identification of letter sounds. The findings of the study revealed that pupils performed better when taught using Jolly Phonics method in identification of letter sounds.

- Ho2: There is no significance difference in the posttest mean scores of pupils' formation of letter sounds and the pre-test scores.

\begin{tabular}{|c|c|c|c|c|c|c|c|}
\hline Variable & No & Mean X & SD & Df & t-cal value & t-crit & Decision \\
\hline Pre-test & 100 & 0.3 & 0.1 & & & & \\
\hline Post-test performance & 100 & & & 319 & 6.93 & 1.97 & Ho Rejected \\
\hline
\end{tabular}

Table 5: $t$-Test Analysis between the Pre-Test and Posttest of Pupils in Formation of Letter Sounds of Primary School Pupils in Zamfara State

As shown in Table 5. The Calculated t-cal value (6.93) is > than the t-crit (1.97) for 320 degree of freedom at 0.05 alpha level of significance. This indicates that the null hypotheses which stated that there is no significant difference in the mean scores of pupils' posttest scores in formation of letter sounds and the pre-test scores, is rejected. Therefore, the alternative hypothesis is upheld that means that there is positive significant difference between the pre-test performance 
of the pupils and posttest performance formation of letter sounds. The findings of the study revealed that pupils performed better when taught using Jolly Phonics method in formation of letter sounds.

\section{Discussion and Findings}

Going by the analysis of the data, the findings revealed that;

There was a statistically significant difference between the Pre-test performance and the posttest performance in the knowledge of identification of letter sounds. This is in line with findings from other literatures.

There was a statistically significant difference between the Pre-test performance and the posttest performance in the knowledge of formation of letter sounds; the findings is in agreement with other related empirical studies used in the study as usage of Jolly Phonics method significantly improved pupils' abilities in reading.

\section{Conclusion}

Jolly Phonics Method is important as it affects the behaviour and expectation of both teachers and learners. Jolly Phonics Method can stimulate more than one sense at a time, and, in doing so getting and attention holding. Jolly Phonics Method adopts the direct, systematic and rapid teaching of letter sounds to pupils. This is immediately followed by teaching them how to blend the letter sounds to form words. Jolly Phonics Method led to improved reading achievement of pupils and an increase in teachers' interest in teaching English.

Children taught using Jolly Phonics Method have demonstrated identification, formation, reading and writing skills far ahead of their contemporaries who were taught using other methods. The method is not only fast but it is fun and engaging thus it enables teachers and learners to carry on their teaching and learning task in a participatory environment, motivated when learning and allows them to work at a different pace.

\section{Recommendations}

In view of the findings of this study, the following recommendations were made;Jolly Phonics Method should be fully implemented so as to enable pupils in their knowledge of identification of letter sounds at primary schools,Enough time should be allotted to the teaching of Jolly Phonics as this will help pupils to improve in their skills of formation of letter sounds this eventually leads to reading and writing.

\section{References}

i. Abdullahi, O.E. (2005). "Typology of Research" In Jimoh, S.A. (ED) Methodology; an Inter DisciplinaryApproach. Ilorin. Unilorin Library \& Publication Committee.

ii. Dixon, P., Schagen, I. and Seedhouse, P., (2011). The impact of an intervention on children's Readingandspelling ability in low-income schools inindiaAvailablefromhttp://dx.doi.org/10.1080/09243453.2011.625125 (Accessed 22 March, 2021).

iii. Dougherty, E. (2014). "Effect of separate sampling on classification accuracy" Bioinformatics 30 (2):242 doi:10.1093/bioformatics/btt662 accessed 13 march2021.

iv. Ekpo, C. M., Udosen, A. A., Afangideh, M. E., Ekukinam, T. U., and Ikorok, M. $\quad$ M., $\quad$ (2007). Jolly phonic strategy and the ESL pupils' reading development: A Preliminary Study. A Paper presented at 1st Mid Term Conference held at theUniversity of Ibadan, Oyo State. Available at: http (Accessed:2 ${ }^{\text {nd }}$ April 2021).

v. Ekpo, C. M. (2009). Strategies for the development and sustenance of reading culture inNigeria.JETT 1, 4348.

vi. Ekpo C, (2008). The use of Jolly Phonics to fast Track Reading Scheme in Government Primary School. Pressrelease.

vii. Eshiet, O. (September 2012) Need for Functional Literacy Education Retrieved from http://www.ngrguardiannews.com/emergency-on- education/177296 need for-functional literacy education retrieved $10 / 2 / 2021$

viii. Ijaya, N.A.O. (2000) The Admissibility of Documents under Re-examination an Appraisal Nigerian Law andPractice Journal Council of Legal Education. Nigerian law school vol.4 No.2 pg. 113

ix. Johnston, R. S., \& Watson, J. (2004). Accelerating the Development of Reading, Spelling and Phonemic Awareness. Reading and Writing: An Interdisciplinary Journal. 17, 327357.

x. Johnston, R. S., \& Watson, J. (2005). The Effects of Synthetic Phonics Teaching on reading and Spelling attainment, a seven-year Longitudinal Study. Ediburgh, Scotland: Scottish Executive Education Department.

xi. Lorane, M.R. (2016) Teachers' Perceptions of the Impact of the Jolly Phonics Program on Students' Literacy.Walden Dissertation and Doctoral Studies.

xii. Nworgu, B. G. (2006). Educational Research; Basic Issues and Methodology. Ibadan: Windon Publishers Ltd.

xiii. Ogbemudia, M.I., and Alasa, V.M. (2014).Jolly Phonics Instructional strategy: Apanacea to Reading Difficulty in Childhood Education; Journal of education Research and Behavioural Sciences Vol. 3 (1).

xiv. Watson, J. and Johnston, R.S. (2005). The effects of Synthetic Phonics Teaching on Reading and Spelling Attainment. http://www.scotland.gov.uk/publications/2005/02/20688/52449 